\title{
POSISI BAHASA ARAB DI LEMBAGA PENDIDIKAN
}

\author{
Rifaldi Haji Hukum \\ Sekolah Tinggi Agama Islam Negeri (STAIN) Sorong, Papua Barat, Indonesia \\ Email : rifaldihaji27@gmail.com
}

\begin{abstract}
ABSTRAK
Bahasa Arab sebagai salah satu bidang studi pokok yang diajarkan di sekolah juga berarti pula tantangan bagi dunia pendidikan untuk berperan dalam era teknologi baru, era informasi tersebut berarti memunculkan suatu pertanyaan, mampukah dunia pendidikan di Indonesia menyiapkan siswa-siswi yang terampil menggunakan bahasa asing khususnya bahasa Arab dalam menghadapi arus globalisasi teknologi? Jika siswa dapat mengembangkan kemampuan bahasa Arabnya dengan baik, maka siswa diharapkan lebih siap menghadapi ledakan teknologi dan berkembang seiring dengan kemajuan teknologi.
\end{abstract}

\section{PENDAHULUAN}

Bahasa Arab salah satu bidang studi pokok yang diajarkan di sekolah juga berarti pula tantangan bagi dunia pendidikan untuk berperan dalam era teknologi baru, jika penguasaan bahasa Arab yang baik itu penting bagi siswa di Indonesia, karena prestasi belajar merupakan cerminan hasil yang dicapai siswa dalam usaha belajarnya.

Hal ini terlihat dari adanya dukungan lembaga-lembaga asing seperti: Lembaga pengetahuan Islam dan Arab (LIPIA), Asian Muslim Charity Foundation (AMCF), serta kebijakan di sektor pendidikan formal, yaitu bahasa Arab diajarkan secara resmi sebagai bahasa asing di sekolah (Lie, 2004).

Bahasa Arab juga sebagai salah satu bidang studi pokok yang diajarkan di sekolah juga berarti pula tantangan bagi dunia pendidikan untuk berperan dalam era teknologi baru, jika siswa-siswi dapat mengembangkan bahasa Arabnya dengan baik, maka siswa-siswi diharapkan lebih siap menghadapi ledakan teknologi dan dapat berkembang seiring dengan kemajuan teknologi. 


\section{Bahasa Arab Sebagai Mata Pelajaran Sekolah}

Bahasa Arab sebagai mata pelajaran sekolah berdasarkan kurikulum berbasis kompetensi. Pada kurikulum berbasis kompetensi terkandung istilah baru, yaitu kompetensi yang artinya pengetahuan, keterampilan, dan nilai-nilai dasar yang direfleksikan dalam kebiasaan berpikir dan bertindak. Yang disebut dengan kurikulum berbasis kompetensi merupakan perangkat standar program pendidikan yang dapat mengantarkan siswa untuk menjadi kompeten dalam berbagai bidang kehidupan yang di pelajari.

Kurikulum berbasis kompetensi bahasa Arab di semester 1yaitu terdiri dari : menyimak dengan tujuan siswa memahami kosakata dalam berbagai teks lisan, membaca dengan tujuan siswa memahami berbagai teks dalam bentuk narasi, dekskripsi percakapan, serta berbentuk khusus untuk memperoleh informasi, menulis dengan tujuan siswa dapat membuat kesimpulan, menulis dan membuat ringkasan, sedangkan untuk semester dua, kurikulum kompetensi bahasa Arab menambahkan berbiacara dengan tujuan siswa dapat tujuan siswa dapat melaporkan informasi faktual.

\section{Pengertian Prestasi Belajar Bahasa Arab}

pendidikan seberapa tinggi jenjang atau tingkatannya tetap saja tidak bisa dipisahkan dari yang namanya prestasi belajar. Prestasi belajar biasanya didapatkan dari hasil suatu tes. Tes prestasi itu sendiri merupakan alat untuk mengungkapkan keberhasilan seseorang dalam belajar atau bisa dibilang juga hasil yang telah dicapai siswa semasa belajarnya.

Prestasi belajar pada situasi tertentu dapat ditentukan oleh faktor intelgensi dan bakat namun masih ada banyak faktor-faktor lain yang juga ikut berperan. prestasi belajar merupakan penguasan atau keterampilan yang dikembangkan oleh anak didik pada mata pelajaran bahasa Arab dan lazimnya ditunjukkan dengan nilai tes atau nilai diberikan oleh guru. Beberapa fungsi pengukuran prestasi belajar adalah:

a. Sebagai alat untuk menumbuhkan motivasi dalam belajar, dan menyadarkan siswa terhadap tingkat kemampuannya.

b. Sebagai masukkan terhadap siswa sehingga dapat diketahui seberapa jauh dia memahami apa yang dia pelajari. 
c. Sebagai masukan terhadap guru sehingga mengetahui apakah guru tersebut berhasil memberikan atau mengajarkan bahan pelajaran.

d. Sebagai bahan informasi untuk melakukan pemilihan terhadap jurusan yang sesuai dengan kemampuannya.

e. Sebagai bahan informasi terhadap sekolah untuk mengadakan program-program yang meningkatkan kualitas pendidikan sekolah.

\section{Pembelajaran Bahasa}

Pembahasan ini merupakan unsure yang sangat relevan. Karena ada hubungan antara struktur sosial dan variasi bahasa, dengan demikian akan mudah bagi guru dan pelajar untuk mengevaluasi keberhasilan pembelajaran. Sehingga pembelajaran bahasa Arab merupakan pembelajaran bahasa dan kebudayaan arab sekaligus.

Pembelajaran adalah proses penewasaan siswa menggunakan asas pendidikan. Konsep pembelajaran adalah suatu proses dimana lingkungan seseoranng secara disengaja dikelola untuk memungkinkan ia turut serta dalam tingkah laku tertentu, pembelajaran merupakan subjek khas dari pendidikan. Demikian pula dengan adanya pengajaran bahasa Arab semakin kerap dilatih maka akan semakin berkesan dan tidak dilupakan, karena belajar bahasa adalah bagaimana membentuk suatu kebiasaan. Dalam pengajaran bahasa Arab dikenal dengan "bermain peranan" dalam bahasa Arabnya "tamsyil mashad" dan yang lebih kompleks bagi masyrokhiyah.

\section{Permasalahan Belajar Bahasa Arab}

Metode pembelajaran bahasa nampaknya sangat dipengaruhi oleh pendekatan atau al madhol apa yang mendasari seseorang terhadap persepsinya tentang bahasa. Banyak sekali asumsi tentang bahasa misalnya bahasa adalah kebiasaan (al-'adab) dan kebiasaan membutuhkan pengulangan dan pembiasaan. Asumsi lain mengatakan bahwa bahasa adalah habit (al-mulakab) sedang tulisan hanyalah symbol. Yang lain mengatakan bahasa adalah apa yang diucapkan dan bukan apa yang seharusnya diucapkan. Dari sini para pakar mengatakan bahwa pendekatan adalah sejumlah asumsi tentang bahasa. apabila Asumsi tentang orang tentang bahasa adalah lisan maka ia akan mengajarkan bagaimana 
keterampilan berbahasa harus dicapai dan materi apa yang sesuai untuk mencapai tujuan itu.

\section{KESIMPULAN}

1. Bahasa arab sebagai mata pelajaran sekolah berdasarkan kurikulum berbasis kompetensi. Yang disebut dengan kurikulum berbasis kompetensi merupakan perangkat standar program pendidikan yang dapat mengantarkan siswa untuk menjadi kompeten dalam berbagai kehidupan yang dipelajari.

2. Prestasi belajar merupakan penguasaan atau keterampilan yang dikembangkan ol;eh anak didik pada mata pelajaran bahasa Arab dan lazimnya ditunjukkan dengan nilai yang diberikan oleh guru

3. Pembelajaran adalah suatu proses dimana lingkungan seseorang disengaja dikelola untuk memungkinkan ia turut serta dalam tingkah laku tertentu, pembelajaran merupakan subjek khas dari pendidikan.

4. Ada yang mengatakan bahasa adalah apa yang diucapkan dan bukan apa yang seharusnya diucapkan.

\section{DAFTAR PUSTAKA}

Wekke, I. S. (2011). Dukungan Sosial, Optisme dan Prestasi Bahasa Arab, Makassar: UIN Alauddin Press.

Wekke, I. S. (2014). Model Pembelajaran Bahasa Arab. Yogyakarta : Deepublish.

Dr. H. BisriMustofa, M.A dan H.M. Abdul Hamid, M.A. (2012). Metode dan Strategi Pembelajaran Bahasa Arab. Malang: UIN Press. 